\title{
Use of monoclonal antibody against human neutrophil elastase in normal and leukaemic myeloid cells
}

\author{
KAREN A F PULFORD, * WENDY N ERBER, * JULIE A CRICK, * INGE OLSSON, \\ K J MICKLEM, * K C GATTER, * D Y MASON*
}

From the *Nuffield Department of Pathology, John Radcliffe Hospital, Oxford, and the Research Department 2, Lund Hospital, Lund, Sweden

SUMmARY A monoclonal antibody, NP57, was produced and used against the neutrophil granule protein elastase, which selectively stain neutrophils in cryostat and paraffin wax sections. The antibody stains neutrophils and a subpopulation of monocytes in blood smears and neutrophil precursors in bone marrow smears, and gives positive reactions with the cell lines HL60 and U-937. It labelled the blast cells in $68 \%$ of cases of acute myeloid leukaemia (M1-M5) but was unreactive with all cases of lymphoid leukaemias. Most of the elastase negative myeloid leukaemias were labelled by monoclonal anti-myeloperoxidase (antibody MPO-7) as were cells from the promyelocytic line HL60. No cases of myeloid leukaemia showed the opposite pattern-that is elastase positive, myeloperoxidase negative, suggesting that the production of myeloperoxidase precedes the onset of elastase synthesis during myeloid maturation.

The anti-elastase antibody NP57 is a useful addition to the range of monoclonal antibodies available for the differential diagnosis of acute leukaemia by alkaline phosphatase-antialkaline phosphatase (APAAP) labelling of cell smears; it may also be of value for the histopathological diagnosis of tumour deposits in myeloid leukaemia and for the detection of neutrophils in paraffin sections.

The primary and secondary granules of neutrophils contain several different proteins. Some of these have a role in the killing of micro-organisms ${ }^{12}$; others have proteolytic activity and may serve to break down tissue in the vicinity of polymorph accumulations. ${ }^{3-5}$ In the present paper we describe the preparation of a monoclonal antibody NP57 specific for one of these neutrophil granule proteins - the enzyme elastase. Neutrophil elastase is a neutral protease which plays an important part in microbial killing and in initiating tissue injury. ${ }^{\text {In }}$ previous studies (based on differential centrifugation of isolated granules) it has been localised to primary (azurophil) granules. ${ }^{6}$

The monoclonal anti-elastase antibody described here detects a formalin resistant epitope and it can thus be used to label neutrophils in paraffin sections of routinely processed tissue. It is also of value, using the alkaline phosphatase-antialkaline phosphatase (APAAP) immunoalkaline phosphatase technique, for labelling elastase in myeloid cells in blood and bone marrow smears. ${ }^{78}$ The APAAP procedure gives min-

Accepted for publication 18 February 1988 imal background labelling so that trace amounts of elastase can be detected - that is, when it first appears in primary granules during myeloid maturation. This method has also shown that a subpopulation of human monocytes contain small amounts of elastase.

Besides detecting elastase in normal cells, this antibody, together with monclonal anti-myeloperoxidase, has proved to be a valuable addition to a panel of other monoclonal antibodies for phenotyping acute leukaemias.

\section{Material and methods}

Neutrophil granule proteins were extracted from myeloid cells from a patient with chronic myeloid leukaemia according to the technique described by Olsson and Venge. ${ }^{9}$ Briefly, leucocytes obtained after a dextran sedimentation of whole blood were washed, resuspended in $0.36 \mathrm{M}$ sucrose and sonicated. The preparation was spun at $300 \times g$ to remove cell nuclei and the resulting supernatant was centrifuged at 8000 $\times g$ to collect the granules. The granule contents were then extracted for 60 minutes at $4^{\circ} \mathrm{C}$ in $0.34 \mathrm{M}$ sodium 
acetate, $\mathrm{pH} 4 \cdot 0$. The green protein extract was then stored at $-20^{\circ} \mathrm{C}$.

Elastase, myeloperoxidase, and cationic chymotrypsin-like protein were purified from human neutrophils as described previously. ${ }^{9}$

A mouse was injected three times intraperitoneally at eight day intervals with the granule protein emulsified in Freund's complete adjuvant. A fusion was carried out three days after the last injection adhering to the procedure previously described.$^{10}$ Screening was performed by the APAAP immunoalkaline phosphatase procedure on smears of peripheral blood."

Blood and bone marrow samples from haematologically normal patients and those with a variety of haematological disorders were obtained from the haematology department, John Radcliffe Hospital. These were used to make either cell smears of whole blood or cytocentrifuge preparations of mononuclear cells separated on Lymphoprep (Nyegaard). Slides were either stained immediately (after air drying at room temperature) or stored at $-20^{\circ} \mathrm{C}$.

The HL60 promyelocytic cell line and the U-937 histiocytic cell line were grown in RPMI 1640 plus $10 \%$ fetal calf serum, and cytocentrifuge preparations were made.

Paraffin embedded routinely processed tissue samples and fresh tissue samples for crysotat sectioning were obtained from the histopathology department, John Radcliffe Hospital. Cryostat sections were stored frozen until use.

IMMUNOCYTOCHEMICAL LABELLING

Immunoenzymatic technique Immediately before labelling, smears of human peripheral blood or bone marrow, or cytocentrifuge preparations of human leucocytes were brought to room temperature and fixed for 90 seconds in one of the following fixatives: methanol $/ 40 \%$ formalin (equal volumes); acetone/ methanol/formalin (19:19:2 v/v); buffered formol acetone $^{12}$; acetone/methanol (equal volumes).

Staining was performed with the antibody NP57 or with monoclonal anti-myeloperoxidase antibody MPO-7 (kindly provided by Dr T Olofsson) using the APAAP procedure. ${ }^{8113}$ Both of these primary antibodies were used as tissue culture supernatant at an optional dilution determined by preliminary titration. The reagents for the APAAP procedure were obtained from Dakopatts a/s (rabbit anti-mouse immunoglobulin) or prepared in the authors' laboratory (APAAP complexes). ${ }^{11}$

Paraffin wax sections were dewaxed, hydrated, and then immunostained by the APAAP technique. Cryostat sections were fixed in acetone for 10 minutes before APAAP staining.

Immunofluorescence Buffy coat smears of normal peripheral blood and cytocentrifuge preparations of mononuclear cells were fixed in methanol/formalin for 60 seconds and then incubated in a mixture of the monoclonal antibody NP57 (undiluted supernatant) and rabbit anti-lactoferrin ((Dakopatts a/s, used at a final dilution of $1 / 200$ ). After 30 minutes the smears were washed and incubated with a mixture of TRITCswine anti-rabbit Ig (Dakopatts a/s) and fluorescent isothiocyanate-goat anti-mouse Ig (Tago), both antibodies being used at a final concentration of $1 / 30$. Smears were then mounted in polyvinyl alcohol for immunofluorescence microscopy. ${ }^{14}$

In preliminary experiments (to establish optimal dilution of reagents) staining was performed using antibody NP57 or anti-lactoferrin alone, and in some of these experiments different fixatives were evaluated.

\section{DOT BLOT ASSAY}

Samples of neutrophil granule extract (and of other proteins such as purified elastase, column eluates) were dotted in doubling dilution (starting at $3.7 \mathrm{mg} / \mathrm{ml}$ for granule preparation and $0.2 \mathrm{mg} / \mathrm{ml}$ for purified elastase) in aliquots of $100 \mu \mathrm{l}$ on to nitrocellulose paper. Free protein binding sites were blocked by incubation in $3 \%$ bovine serum albumin for 30 minutes. The paper was then stained by the APAAP immunoalkaline phosphatase technique using either the monoclonal antibody NP57, rabbit anti-elastase (produced in one of the authors' (IO) laboratories), or monoclonal anti-T cell antibody Dako-T1 (as a negative control).

\section{IMMUNOAFFINITY PURIFICATION}

Antibody NP57 was isolated from ascitic fluid and coupled to CNBr-Sepharose (Pharmacia) at $5 \mathrm{mg} / \mathrm{ml}$ gel. The granule extract, diluted in $10 \mathrm{mM}$ Tris $150 \mathrm{mM}$ sodium chloride ( $\mathrm{pH} 7 \cdot 2)$, was run through a column of immunoabsorbant. The bound material was eluted with $100 \mathrm{mM}$ glycine $(\mathrm{pH} 2 \cdot 2)$ and subjected to polyacrylamide gel electrophoresis. Fractions eluted from the column were also assayed for elastase activity and, by dot-blotting, for reactivity with rabbit anti-elastase and with antibody NP57.

\section{ELASTASE ASSAY}

Elastase activity was measured using a chromogenic substrate (N-succinyl-alanyl-alanyl-alanine-p-nitroanilide (Sigma). ${ }^{15}$ The substrate was dissolved at a concentration of $22 \mathrm{mM}$ in $50 \mathrm{mM}$ Tris buffer (pH8.0), containing $150 \mathrm{mM}$ sodium chloride and $5 \mathrm{mM}$ calcium chloride. Samples of $200 \mu \mathrm{l}$ were added to $0.8 \mathrm{ml}$ of substrate and incubation performed at $37^{\circ} \mathrm{C}$ for two hours. The yellow reaction product was measured at $400 \mathrm{~nm}$. 


\section{Results}

Screening was performed 12 days after cell fusion and a cell culture was identified which secreted antibody activity directed against human neutrophils in blood smears. These hybrid cells were cloned by limiting dilution and established in permanent culture. The antibody secreted by this hybridoma was designated NP57.

\section{BIOCHEMICAL CHARACTERISATION}

Antibody NP57 was shown by blotting on nitrocellulose paper to bind to the original immunising preparation of neutrophil granule proteins and to purified neutrophil elastase, but not to cationic chymotrypsin-like protein (CCP) or myeloperoxidase (fig 1). No staining of these preparations was obtained with the control monoclonal anti-T cell antibody.

The material from the NP57 immunoaffinity column was shown on sodium dodecyl sulphate (SDS) gel electrophoresis under reducing conditions to consist of three bands of 23-27 kD molecular weight (fig 2). The fractions containing this material (but not the other column fractions) possessed elastase activity (fig 3). Dot blotting showed that this material was recognised both by the polyclonal rabbit anti-elastase and by antibody NP57 (fig 3).

\section{IMMUNOCYTOCHEMICAL STAINING WITH MONOCLONAL ANTI-ELASTASE}

Tissue sections The antibody was tested on routine paraffin wax embedded samples from a variety of human tissues, and strong labelling of neutrophils was obtained (figs 4 and 5). No staining of other cells or elements in the tissue sections was observed. In crysotat sections staining of neutrophils was seen but, in contrast to the staining seen on paraffin sections, this formed an indistinct "cloud" of staining overlying individual cells (fig 6), preventing their clear visualisation and suggesting that diffusion of the antigen out of neutrophils occurs when cryostat sections thaw.

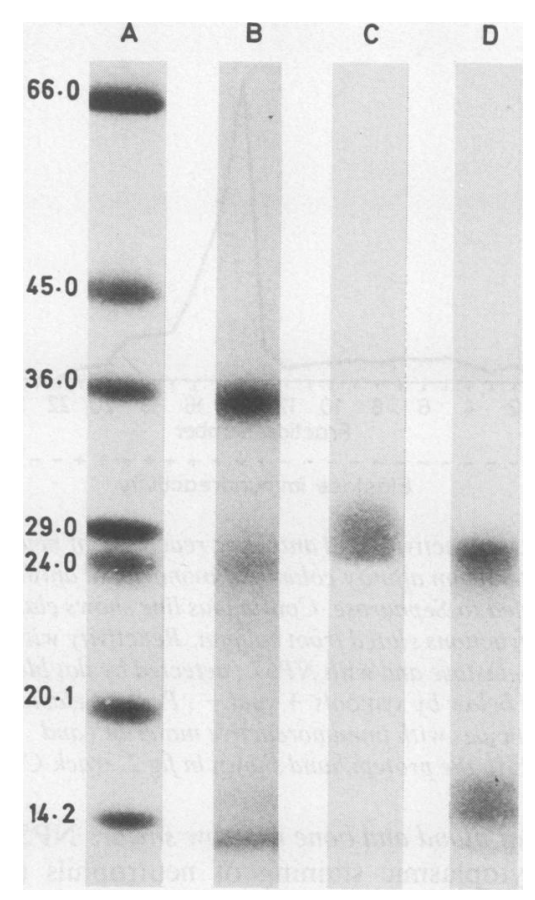

Fig 2 Characterisation of antibody NP57 by affinity chromatographic separation of neutrophil granule proteins. All tracks show SDS polyacrylamide gel electrophoresis of proteins.

Track A, molecular weight markers (values in $K D a$ ); track $B$, granule proteins prepared from human neutrophils; track C, protein eluted from an affinity column of antibody NP57 after loading with the neutrophil granule preparation consists of a diffuse band of about $25 \mathrm{Kd}$. In other experiments (not shown) this material could be resolved into three closely spaced bands.

Track D, control preparation of previously purified human neutrophil elastase, ${ }^{9}$ showing prominent band of comparable molecular weight to protein seen in track $C$ (together with lower molecular weight components).

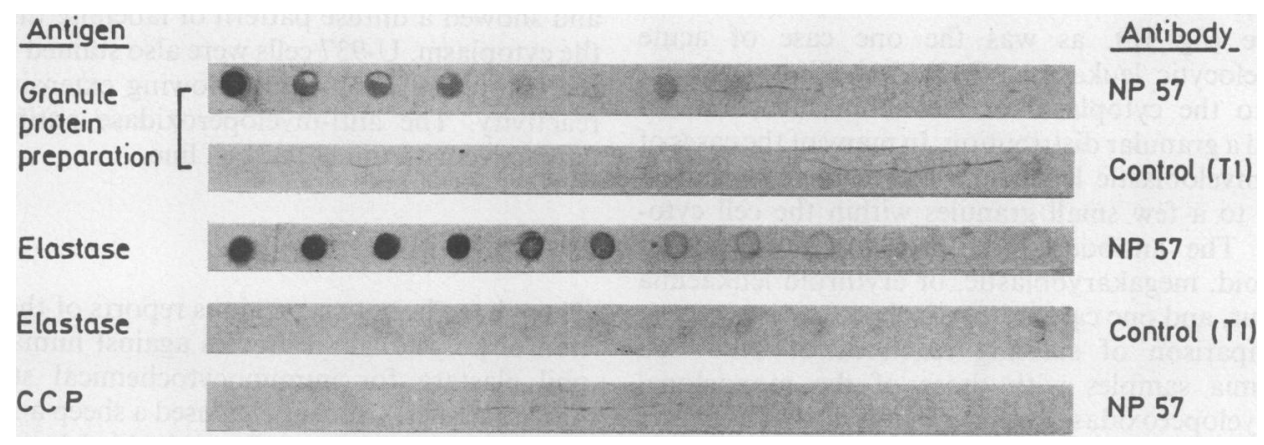

Fig 1 Reactivity of antibody NP57 with neutrophil granule proteins. There is no non-specific binding of an unrelated monoclonal antibody (T1) to granule protein preparation or to purified elastase. 


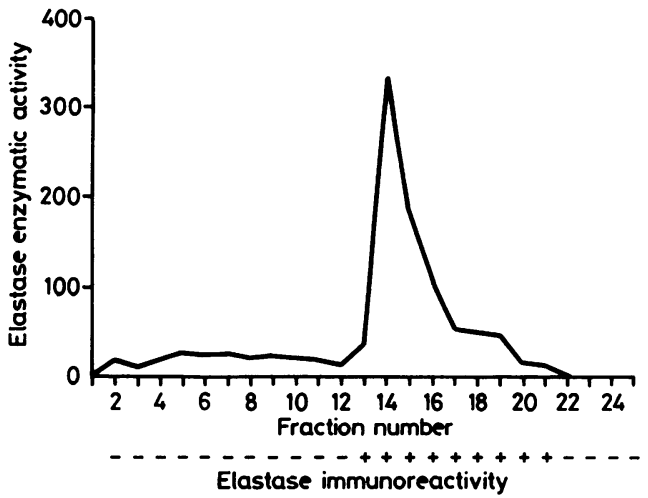

Fig 3 Elastase activity and antigenic reactivity of neutrophil protein eluted from affinity column of monoclonal antibody NP57 coupled to Sepharose. Continuous line shows elastase activity of fractions eluted from column. Reactivity with rabbit anti-elastase and with NP57 (detected by dot blotting) is indicated below by symbols + and - . Peak of elastase activity coincides with immunoreactive material (and corresponds to the protein band shown in fig 2, track C)

Staining of blood and bone marrow smears NP57 gave strong cytoplasmic staining of neutrophils (fig 7), usually in a granular pattern, and of neutrophil precursors. No staining of eosinophils was seen.

A minor population of monocytes in peripheral blood was labelled by NP57, usually in the form of small granules localised to one region of the cytoplasm (fig 8). Double immunofluorescence labelling for NP57 and lactoferrin (a protein confined to secondary granules in neutrophils) confirmed the existence of this population of NP57 positive, lactoferrin negative cells (fig 9).

NP57 was tested for reactivity on blood and bone marrow smears from cases of haematological malignancy (table). Neoplastic cells in 13 of 21 cases of acute myeloblastic leukaemia (M1, M2), 16 of 22 cases of acute myelomonocytic leukaemia (M4), and four of six cases of acute monoblastic leukaemia (M5) were reactive (fig 10), as was the one case of acute promyelocytic leukaemia (M3). Labelling was confined to the cytoplasm of the neoplastic cells and showed a granular distribution. In many of the cases of acute myeloblastic leukaemia the reactivity was restricted to a few small granules within the cell cytoplasm. The antibody did not stain any cases of lymphoid, megakaryoblastic, or erythroid leukaemia (22, four, and one case, respectively).

Comparison of staining reactions of NP57 on leukaemia samples with those of the monoclonal anti-myeloperoxidase antibody showed that a greater proportion of the myeloid malignancies $(91 \% v 68 \%)$ were stained by anti-myeloperoxidase antibody.

One interesting aspect of blood smear labelling was
Table Reactivity of monoclonal antibodies to elastase (NP57) and myeloperoxidase (MPO-7) with haematological neoplasms

\begin{tabular}{|c|c|c|}
\hline & NP57 & $M P O-7$ \\
\hline $\begin{array}{l}\text { Acute limphoblastic leukcuemias: } \\
\text { C-ALL } \\
\text { T-ALL }\end{array}$ & $\begin{array}{l}0 / 14 \\
0 / 8\end{array}$ & $\begin{array}{l}0 / 10 \\
0 / 5\end{array}$ \\
\hline $\begin{array}{l}\text { Acule non-lymphohlastic leukaemias: } \\
\text { AML (M1. M2) } \\
\text { APL (M3) } \\
\text { AMML (M4) } \\
\text { AMoL (M5) } \\
\text { Ery (M6) } \\
\text { AMKL (M7) }\end{array}$ & $\begin{array}{l}13 / 21(62 \%) \\
1 / 1 \\
16 / 22(73 \%) \\
4 / 6 \\
0 / 1 \\
0 / 4\end{array}$ & $\begin{array}{l}14 / 15(93 \% \\
\text { Not tested } \\
18 / 20(90 \% \\
2 / 2 \\
0 / 1 \\
0 / 3\end{array}$ \\
\hline $\begin{array}{l}\text { Chronic limphoproliferative disorders: } \\
\text { Hairy cell leukaemia } \\
\text { B-cell chronic lymphocytic leukaemia } \\
\text { Waldenstrom's macroglobulinaemia } \\
\text { Multiple myeloma } \\
\text { Sezary syndrome }\end{array}$ & $\begin{array}{l}0 / 4 \\
0 / 7 \\
0 / 1 \\
0 / 3 \\
0 / 2\end{array}$ & $\begin{array}{l}0 / / 4 \\
0 / 4 \\
0 / 1 \\
0 / 4 \\
0 / 1\end{array}$ \\
\hline
\end{tabular}

that in the intracellular localisation of elastase as shown by NP57 depended on the fixative used. Fixation with methanol formalin (50:50) gave the clearest localisation to neutrophil cytoplasm, whereas use of a variety of other fixatives (such as acetone or acetone/methanol/formalin) led to the antigen being localised principally to neutrophil (and monocyte) nuclei. In these preparations staining was strongest at the periphery of the nuclei, the cytoplasm of these cells often being only weakly stained or negative.

This phenomenon was explored most extensively in cell smears stained by the APAAP procedure, but it was also seen in several experiments in which immunofluorescence was used as the staining technique.

\section{STAINING OF CELL LINES}

When HL60 cells were stained for elastase with NP57, about $50 \%$ were labelled, often in a localised area within the cytoplasm. In contrast, antimyeloperoxidase stained all cells in the HL60 cell line, and showed a diffuse pattern of labelling throughout the cytoplasm. U-937 cells were also stained by NP57, the cytoplasm of all cells showing extensive strong reactivity. The anti-myeloperoxidase antibody was unreactive with the U-937 cell line.

\section{Discussion}

There have been two previous reports of the preparation of polyclonal antibodies against human neutrophil elastase for immunocytochemical staining of human tissues. Crocker $e t$ al used a sheep anti-elastase antiserum to stain paraffin embedded human tissue, and noted strong granular labelling confined to neutrophils and eosinophils (with the exception of 

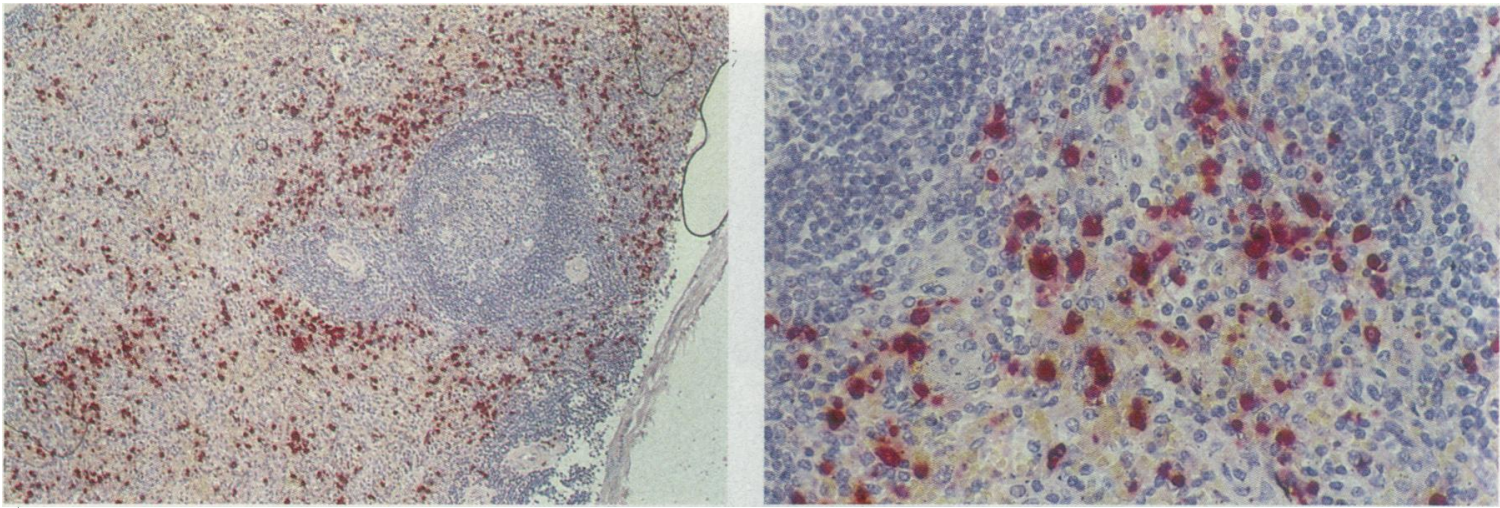

Fig 4 Immunostaining of neutrophils in paraffin wax embedded section of normal human spleen with the monoclonal antielastase antibody NP57 (APAAP technique)

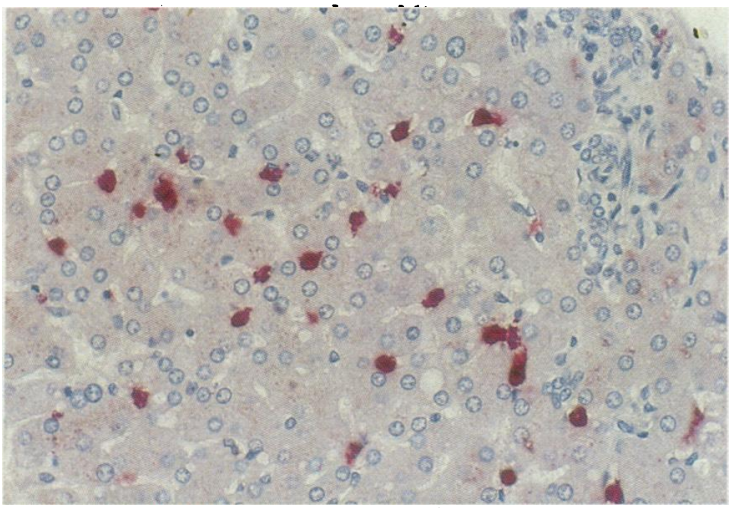

Fig 5 Neutrophils in paraffin wax embedded human liver sharply demarcated by immunostaining for elastase with antibody NP57 (APAAP technique)

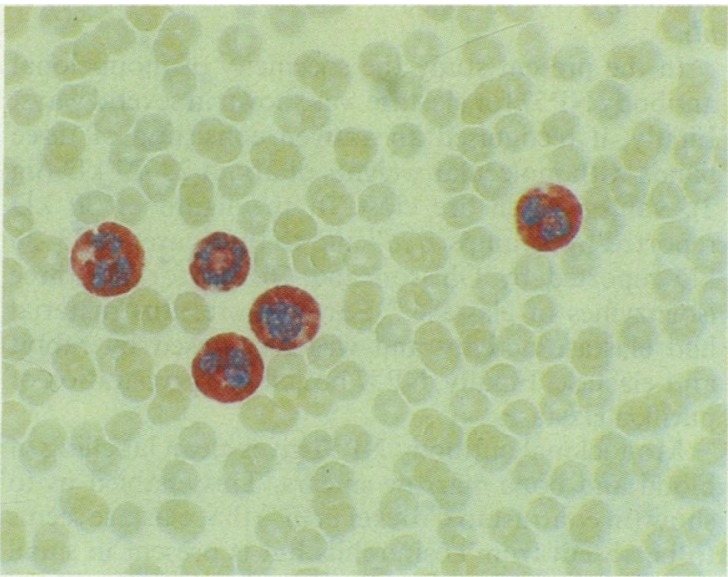

Fig 7 Staining of buffy coat smear from normal blood with antibody NP57 shows strong labelling of neutrophil cytoplasm (APAAP technique)

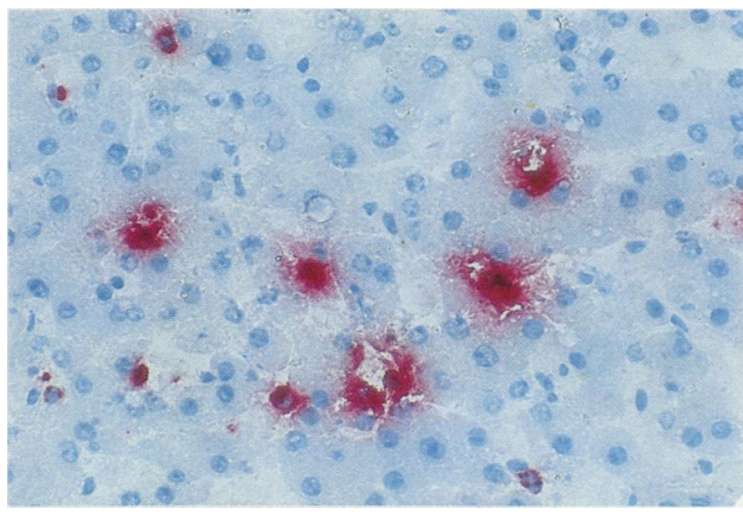

Fig 6 Staining of human liver in cryostat section shows clearly different distribution to that seen in paraffin wax section (compare with fig 5), indicating diffusion of elastase from neutrophils (APAAP technique)

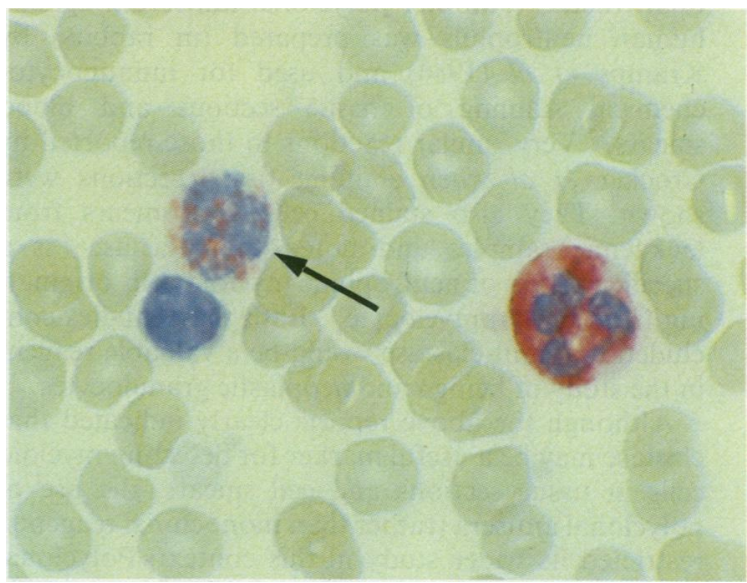

Fig 8 Staining of buffy coat smear with antibody NP57 shows one strongly labelled neutrophil and also an elastase positive monocyte (arrowed) in which labelling is characteristically weaker (APAAP technique) 


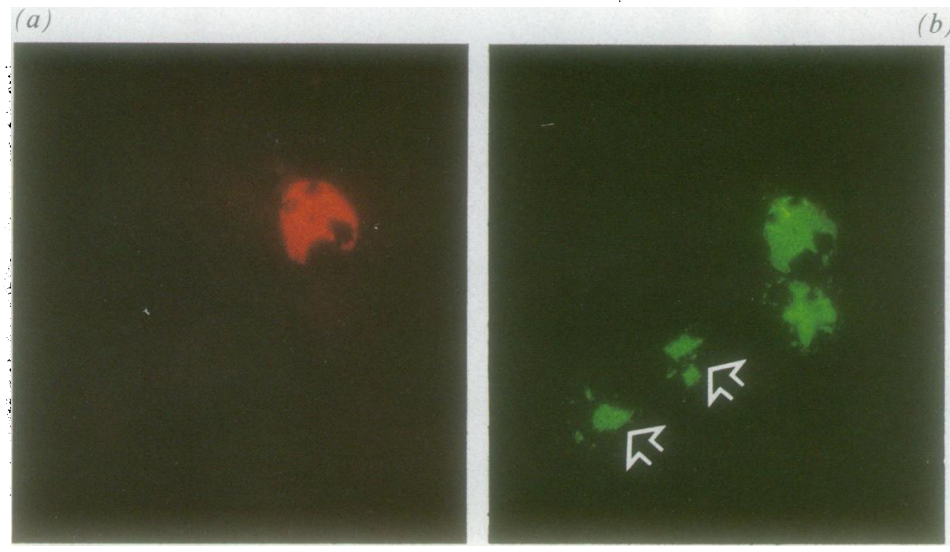

Fig 9. Paired immunofluorescence labelling of normal peripheral blood cytospin with ( $a$ ) anti-lactoferrin and ( $b$ ) anti-elastase. A neutrophil is seen which contains both of these markers. Two NP57 positive monocytes are also seen (arrows) which lack lactoferrin.
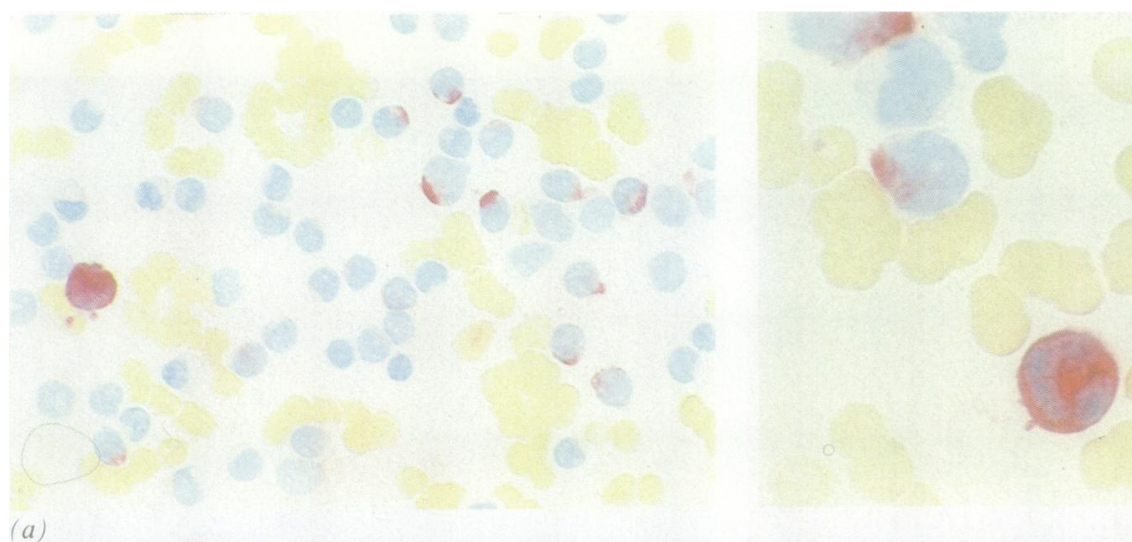

Fig 10 (a) Staining of bone marrow smear from case of acute myeloid leukaemia using monoclonal anti-elastase antibody NP57 shows numerous strongly stained blast cells (APAAP technique). (b) Higher power view showing localised cytoplasmic pattern of staining.

weaker staining of epithelial cells in the gastrointestinal tract). ${ }^{16}$ Another polyclonal antiserum against human neutrophils was prepared (in rabbits) by Kramps et al (1984) and used for immunocytochemical staining of tissue sections and blood smears. ${ }^{17}$ Very similar reactions to those reported by Crocker et al when staining tissue sections were shown. They also stained cells and smears from leukaemic samples and noted that elastase "is a specific marker of neutrophilic myeloid cells originating from the promyelocyte". Both these studies concluded that anti-elastase would be a valuable reagent in the study of benign and neoplastic granulocytes.

Although the above reports clearly indicated that elastase may be a useful marker for detecting myeloid cells in tissue sections and cell smears, the use of polyclonal antisera (rather than monoclonal reagents) restricted its wider study in this context. Polyclonal antisera also introduce a potential risk of non-specific reactivity and background labelling in immunocytochemistry. This may account for minor discrepancies between the two reports (such as the eosinophil labelling noted by Crocker $e t$ al but not by Kramps $e t$ $a l)$.

In the present study the specificity of monoclonal antibody NP57 for elastase was shown in several ways. Firstly, it recognised an antigen consisting of three bands with molecular weights of about 23-27 kD (fig 2), values which are close to the figure of $30 \mathrm{kD}$ reported by Kramps et $\mathrm{al}^{17}$ and to the figures of 33-36 kD reported by Ohlsson and Olsson for the three isoenzymes of elastase. ${ }^{18}$ Furthermore, this material had elastase activity and was recognised by rabbit anti-elastase. Finally, NP57 bound to a preparation of purified elastase.

Monoclonal antibody NP57 gives clean labelling of blood and bone marrow smears. This enabled us to show (in contrast to Crocker et $\mathrm{al}^{16}$ ) that elastase seems to be absent from eosinophils but is present in small amounts in monocytes. Previous studies, based on polyclonal antisera, have suggested that tissue mononuclear phagocytes and circulating monocytes lack 
elastase. ${ }^{1617}$ In the study by Pryzwansky et al, however, elastase was present in about $3 \%$ of cultured monocytes. ${ }^{19}$ More recent work by Senior et al has shown that monocytes and the monocyte-like cell line U937 contain elastase which is biochemically and immunologically similar or identical with neutrophil elastase. ${ }^{20}$ Our own findings on these two cell types support this observation.

The fact that the intracellular distribution pattern of elastase, shown by staining cell smears with NP57, depends on the fixative used is of interest as it indicates that elastase can be eluted out of the neutrophil cytoplasm during the fixation process and then bind to the cell nucleus. Similar findings have been reported in the case of lactoferrin, ${ }^{21}$ a neutrophil protein which in early immunocytochemical studies was documented as being a nuclear constituent. ${ }^{22}$ It has been clearly established in other studies, however, as a constituent of neutrophil cytoplasmic secondary granules and its apparent nuclear localisation has been shown to be a fixation artefact. ${ }^{21}$

The results of our study show that the true localisation of elastase in vivo is in the cell cytoplasm (rather than within nuclei), and this is supported by the way in which the enzyme behaves during cell fractionation and granule purification, and also by ultrastructural labelling studies (Cramer et al, unpublished observations). These findings, seen both for elastase and for lactoferrin, provide an instructive example of how artefacts can arise when attempting to identify the subcellular location of an antigenic molecule by immunocytochemistry.

Staining of blood and bone marrow smears with NP57 can be used in the diagnosis of acute myeloid leukaemias. We have previously reported an evaluation of more than 250 haematological samples which showed the practical value of the APAAP staining procedure (as applied to routine blood and marrow smears) for this purpose. ${ }^{13}$ It became evident during this work, however, that there are at present relatively few satisfactory markers that can be used by this technique for the detection of myeloid leukaemias. Monoclonal antibodies My4, My7, and My9, ${ }^{23}$ which probably represent the best currently available reagents of this sort, give relatively weak labelling on cell smears. In contrast, the reactivity of the monoclonal anti-elastase antibody NP57 reported in this paper is often strong, probably because of the fact that elastase is present in neutrophil granules at relatively high local concentration (unlike surface antigens which are diffusely distributed in the cell membrane).

In our study the anti-myeloperoxidase monoclonal antibody MPO-7 labelled neoplastic cells in a greater proportion of myeloid leukaemias than NP57 (91\% v $68 \%$ ). This suggests that myeloperoxidase is expressed at an earlier stage of myeloid differentiation than elastase and is thus able to detect more immature myeloblasts. The fact that the HL60 line expresses myeloperoxidase in all cells, but elastase in only a proportion, also supports this view. The observation that the cell line U-937 lacked myeloperoxidase but was strongly positive for elastase is not in keeping with this hypothesis. This pattern may represent loss during in vitro culture of U-937 of the ability to express myeloperoxidase (as elastase was never found in the absence of myeloperoxidase in fresh myeloid leukaemia cells). Alternatively, the U-937 cell line may not reflect events during granulocytic maturation because of its histiocytic nature.

In conclusion, the monoclonal anti-elastase antibody NP57 described in this paper is of potential value in studies of the maturation and other aspects of normal myeloid cells. It also seems to represent a useful addition to the existing range of monoclonal antibodies for immunocytochemical labelling of cell smears in the differential diagnosis of acute leukaemia. It may also provide a means of diagnosing solid deposits of myeloid leukaemia and of detecting myeloid infiltrates in paraffin sections.

This work was supported by the Leukaemia Research Fund. KC Gatter is a Wellcome Senior Research Fellow.

\section{References}

I Klebanoff SJ, Hamon CB. Role of myeloperoxidase mediated anti-microbial systems in intact leucocytes $J$ Reticuloendothelial Soc 1972;12:170-96.

2 Arnold RR, Cole MF, McGhee JR. A bactericidal effect for human lactoferrin. Science 1966;197:283-90.

3 DeDuve C, Wattiaux R. Function of lysosomes. Ann Rev Physiol 1966;28:435-60.

4 Janoff A, Sandhaus RA, Hospelhorn VD, Rosenberg R. Digestion of lung proteins by human leukocyte granules in vitro. Proc Soc Exp Biol Med 1972;140:516-9.

5 Starkey PM. Elastase and cathepsin G. The serine proteases of human neutrophil leucocytes and spleen. In: Barrett $\mathrm{AJ}$, ed. Research monographs in cell and tissue physiology. Vol 2. Proteinases in mammalian cells and tissues. Amsterdam: North Holland Publishing, 1979;57-89.

6 Dewald B, Rindler-Ludwig R, Bretz U, Baggiolini M. Subcellular localization and heterogeneity of neutral proteases in neutrophilic polymorphonuclear leukocytes. $J$ Exp Med 1975;141:709-23.

7 Erber WN, Pinching AJ, Mason DY. Immunocytochemical detection of $\mathrm{T}$ and $\mathrm{B}$ cell populations in routine blood smears. Lancet 1984;i:1042-5.

8 Mason DY. Immunocytochemical labelling of monoclonal antibodies by the APAAP immunoalkaline phosphatase technique. In: Bullock GR, Petrusz P, eds. Techniques in immunocytochemistry. Vol 3. London: Academic Press 1985:25-42.

9 Olsson I, Venge P. Cationic proteins of human granulocytes. I. Isolation of the cationic proteins from the granules of leukaemic myeloid cells. Scand J Haematol 1972;9:204-10.

10 Mason DY, Cordell JL, Pulford KAF. Production of monoclonal 
antibodies for immunocytochemical use. In: Bullock GR, Petrusz P, eds. Techniques in Immunocytochemistry. Vol 2. London: Academic Press, 1983:175-216.

11 Cordell JL, Falini B, Erber WN, et al. Immunoenzymatic labelling of monoclonal antibodies using immune complexes of alkaline phosphatase and monoclonal anti-alkaline phosphatase (APAAP complexes). J Histochem Cytochem 1984;29:219-29.

12 Mason DY, Farrell C, Taylor CR. The detection of intracellular antigens in human leucocytes by immunoperoxidase staining. Br J Haematol 1975;31:361-70.

13 Erber WN, Mynheer LC, Mason DY. APAAP labelling of blood and bone-marrow samples for phenotyping leukaemia. Lancet 1986;i:761-5.

14 Valnes K, Brandtzaeg P. Retardation of immunofluorescence fading during microscopy. J Histochem Cytochem 1985;33: 755-61.

15 Bieth B, Spiess B, Wermuth CG. The synthesis and analytical use of a highly sensitive and convenient substrate of elastase. Biochem Med 1974;11:350-5.

16 Crocker J, Jenkins $R$, Burnett D. Immunohistochemical demonstration of leucocyte elastase in human tissues. $J$ Clin Pathol 1984;37:1114-8.

17 Kramps JA, Van der Valk P, Van der Sandt MM, et al. Elastase as a marker for neutrophilic myeloid cells. J Histochem Cytochem 1984;32:389-94.

18 Ohlsson K, Olsson I. The neutral proteases of human granulocytes. Isolation and partial characterization of granulocyte elastases. Eur J Biochem 1974;42:519-27.

19 Pryzwansky KB, Martin LE, Spitznagel JK. Immunocytochemical localisation of myeloperoxidase, lactoferrin, lysozyme and neutral protease in human monocytes and neutrophilic granulocytes. $J$ Reticuloendothelial Soc 1978;24:295-310.

20 Senior RM, Campbell EJ, Landis JA, et al. Elastase of U-937 monocytelike cells. Comparisons with elastases derived from human monocytes and neutrophils and murine macrophage like cells. J Clin Invest 1982;69:384-93.

21 Briggs RC, Glass WF, Monteil MM, Hnilica LS. Lactoferrin: nuclear localisation in the human neutrophilic granulocyte. $J$ Histochem Cytochem 1981;29:1128-36.

22 Green I, Kirkpatrick H, Dale LC. Lactoferrin; specific localisation in the nuclei of human polymorphonuclear neutrophilic leucocytes. Proc Soc Exp Biol Med 1971:137:1311-6.

23 Griffin JD, Davis R, Nelson DA, et al. Use of surface marker analysis to predict outcome of adult myeloblastic leukaemia. Blood 1986;68:1232-41.

Requests for reprints to: Dr D Y Mason, Department of Haematology, John Radcliffe Hospital, Headington, Oxford OX3 9DU, England. 